\title{
Changing Attitudes Towards Territorial Municipal Reforms - The Case of Inland Norway
}

\author{
Ulla Higdem, Hans Christian Høyer, Jon Helge LeSJø \& ERIK NeSLEIN \\ MØNNESS
}

\begin{abstract}
Inland people's attitude towards municipal amalgamation reform in Norway from 2013 to 2018 has become more positive. However, a majority does not support the ongoing reform, but the changes have been substantial during such a short time period. However, these changes seem not to be a result of new and more positive judgements of the reforms' results and outcome. By contrast, the majority has been more critical of anticipated consequences of the amalgamation reform into larger municipalities. Instead, we considered the changes as a type of 'resignation' towards a reform pressure from the national government and general changes in their environment. More citizens' assess that positive municipal economic development and more local competence are favourable effects of mergers, and this finding supports this claim. The reform is likely to catch up with their local units anyway, and the citizens' attitudes are adapting to what they expect will occur in the upcoming years.
\end{abstract}

Keywords: - municipal amalgamation - territorial reforms • citizens' attitudes $\bullet$ anticipated consequences $\bullet$ Norway

Correspondence Address: Ulla Higdem, Ph.D., Associate Professor, Inland Norway University of Applied Sciences, Inland School of Business and Social Sciences, Postbox 400, 2418 Elverum, Norway, email: ulla.higdem@inn.no. Hans Christian Høyer, Inland Norway University of Applied Sciences, Inland School of Business and Social Sciences, Postbox 400, 2418 Elverum, Norway, email: hans.hoyer@inn.no. Jon Helge Lesjø, Inland Norway University of Applied Sciences, Inland School of Business and Social Sciences, Postbox 400, 2418 Elverum, Norway, email: jon.helge.lesjo@inn.no. Erik Neslein Mønness, Inland Norway University of Applied Sciences, Inland School of Business and Social Sciences, Postbox 400, 2418 Elverum, Norway, email: erik.monness@inn.no.

https://doi.org/10.4335/18.2.271-292(2020)

ISSN 1581-5374 Print/1855-363X Online C) 2020 Lex localis

Available online at http://journal.lex-localis.press. 
Territorial reforms are the most radical and often contested reorganisation of local and regional levels of a nation (Ebinger, Kuhlmann, \& Bogumil, 2019). Because territorial reforms in the sense of up-scaling or amalgamation influence European national politics from one country to another in a regular manner, such reforms have received scholarly attention (Baldersheim and Rose, 2010). From the 1970s until today, the number of municipalities across European countries has substantially declined (Ebinger et al., 2019). In the period of 2008 to 2017, 15 European countries have undergone territorial reforms, and the number of municipalities has decreased by more than 5000 ((Swianiewicz, 2018). Australia has also experienced what is called municipal amalgamation programmes of an episodic nature, another much contested and debated topic (Ryan et al., 2016).

Changes in sub-national organisation are of great importance for local welfare policy and local democracy in most European countries (Bouckaert and Kuhlmann 2016). Norway, among the Scandinavian countries, is no exception to this trend, and this topic received new actuality when the conservative Solberg government entered office after the general election in 2013. This right-wing government of the Conservative Party and the Progress Party had prioritised the municipal reform of reducing the number of municipalities considerably (Klausen, Askim and Vabo, 2016). The government's main objective was to secure professional welfare services and to develop sustainable entities, also securing local planning and democracy.

From 2013 to 2017 a national lead political process ended with a decision in parliament to reduce the number of municipalities from 428 to 356. In 2014, the majority in the parliament decided to include the regions into the reform programme, resulting in a decision to reduce the number of counties from 19 to 11. The implementation date of the territorial reforms affecting municipalities and counties is 1 January 2020.

The government wanted political consensus and the largest possible coalition behind the reform, but this was not possible in parliament or in local politics, especially in rural areas, because this topic also activated a strong centre-periphery cleavage in Norwegian politics (Rokkan, 1987). Therefore, the government only achieved the lowest necessary majority in favour of the reform. Nonetheless, the government prioritised the implementation of the reform and insisted on continuing the reform beyond 2020 .

This article focuses on the citizens' attitudes towards the municipal reform. This topic has only been briefly studied outside the Scandinavian countries. Several studies conducted in Norway have been based on national samples. This article focuses on the developments in the citizens' attitude to amalgamation reforms in 
a period with political cleavages and public debate connected to the reform. The research question is if and how citizens' attitudes towards reducing the number of municipalities have changed during the national reform process.

This article is based on data from the Inland region in Norway, a region comprising 48 municipalities and two counties. No amalgamation of municipalities was decided in the actual period, and the two counties were merged after a political decision in parliament even if the county councils voted against the reform. The region has a territory larger than Denmark, a substantial distance from south to north, and may be characterised as an inland periphery.

The data is from two surveys drawn from representative samples in Inland Norway at two different times: in 2013 and 2018. The first data set is from the start of the reform process, and the second is drawn at the time the national policy process had concluded upon where municipalities are going to merge. At this time, the national government's message was to continue the reform process beyond 2020 .

Studies of human actions and attitudes may be built on assumptions of rational individuals motivated by self-interest and social actors embedded in a community of others (Christensen, Lægreid, \& K.A, 2015; Grenwood, Oliviver, Sahlin, \& Suddaby, 2008; Hall \& Taylor, 1996). The rational self-interest-oriented individual calculates what to do in different situations according to her or his interests (Hardin R, 2002) For the social individual, conforming to common values, history, and identity is critical (March \& Olsen, 1995). From a rational choice perspective, we expect citizens' attitude to reforms to be a result of their interests and calculations of what they will benefit from. The social actor will be strongly influenced by her or his commitment to the values in an established order and institutions, which slowly passes through changes.

Consequently, from a rational perspective our empirical expectations are as follows: i) A clear an unambiguous connection will be observed between citizens' estimation of cost and benefits with municipal amalgamation and their stand regarding the merging of their own municipality. ii) Changing assumptions will be directly followed by a new stand regarding the reform. iii) The individual attitudes to reform reflect the stand of an individual's preferred political party.

From a social-embedded perspective, our empirical expectations are as follows: i) There is no necessary connection between the citizens' assumptions of their own cost and benefits from a municipal merger and their own stand on the topic. ii) Resistance to reforms reduces over time independent of the assumption of cost and benefits. iii) Citizens' evaluations are generally influenced by their belonging to and identification with, for instance, political values, parties, and groups, and what they consider an appropriate stand in their community of residence. 
Similar to many other European countries', municipal reform introducing amalgamation of small units into larger units has been contested in Norwegian politics (Baldersheim \& Rose, 2010). A substantial body of literature has investigated impacts (ex-post) of territorial reforms, and especially from the Nordic countries (Ebinger et al., 2019; Swianiewicz, 2018). However, our systematic search for literature on citizens' ex-ante attitudes to municipal or county amalgamation indicated that the literature has been scarce.

In a Swiss context Calciolari, Cristofoli, and Macciò (2013), claim that citizens seem to support municipal amalgamations understood as showing a high degree pf civic consciousness. Verhoeven and Duyvendak (2016) address how collective political actors appeal to citizens opinions and feelings regarding amalgamation and, in general, claim that citizens' do feel 'threatened, afraid, disempowered, frustrated or angry' (Verhoeven \& Duyvendak, 2016, p. 468) regarding such policy interventions, and that such feelings are rational. By attributing rationality to such feelings towards municipal amalgamation policy, these researchers also dismiss NIMBY (not in my back yard) as a type of argument that also supports the notion of 'the irrational citizens' (Verhoeven \& Duyvendak, 2016). In their case from the amalgamation of The Hague, Verhoeven and Duyvendak explain how citizens' views and actions on (against) territorial reform by policy processes and discourses appealed to citizens' emotions. Consequently, they argue that such analysis is critical for understanding failing implementation and a lack of legitimacy (Verhoeven \& Duyvendak, 2016).

In our literature review, we find studies of citicens' ex-ante attitudes to municipal amalgamation also from Canada and Austalia (Kushner\& Siegel, 2003; Poel 2000; Ryan et. al., 2016). Suveys of citicens attitudes are context sensitive and related to the public and political discourse in the actual time and periode. Even though there are interesting findingas also outside Europe, as the plain fact that municipal amalgamation seems to be a contested issue amongst citicens everywhere, we will delimit ourselves to the Europan findings on this issue.

Since 2000, several surveys have been conducted on citizens' attitudes regarding municipal amalgamation in Norway (Johnsen \& Klausen, 2006; Lawrence Rose $\&$ Pettersen, 2003; Lawrence Rose \& Pettersen, 2005).

Rose and Pettersen employe three perspectives related to citizens' perspectives. First, the principal perspective is the citizens' general stance on reducing the number of municipalities. Second, the contextual perspective is the inhabitant's attitude towards merging the individual's own municipality with the neighbouring municipality. The third perspective is the inhabitants' willingness to pay more in 
taxes as an alternative to amalgamation, and how this affects the attitudes on amalgamation - called the cost-contingent perspective.

Johnsen and Klausen (2006) propose including a third perspective in addition to the two hegemonic discourses in the debate: the economic utility perspective (topdown) and the local democracy perspective (bottom-up), a resource-dependent and power-dependent perspective inspired by the strategy-field in organisational theory. This perspective considers the municipality to be a collection of resources, where the municipality and its citizens are selecting the option that sustains the control (power) of resources in their own municipality and preventing mergers, for example, between a small and large municipality. This phenomenon might often be the case with small municipalities on the fringe of a larger municipality. Johnsen and Klausen have launched 'the small town rule': 'The voters in the municipality having the largest population and town centre will be the most positive regarding a proposal of a municipal merger, provided there are substantial differences in size between the largest and the other localities' (Johnsen \& Klausen, 2006, p. 35).

The overall result from the early-2000 studies suggests an equal division of the population between proponents and opponents to municipal amalgamations. However, when the question is amalgamation with your neighbouring municipality, the opposition and scepticism increases. As for the other studies (Ryan et al., 2016), factors such as gender, education, and income have significance; for example, being male, having a higher education, and an average to good income is more likely be in favour of municipal amalgamation in principle and in the contextual perspective. Citizens' affiliation to a party is, however, notable because of the stronger explanation of attitudes regarding municipal amalgamation (Jacobsen, 2004; Lawrence Rose \& Pettersen, 2003; Lawrence Rose \& Pettersen, 2005). Data from referendums on municipal mergers indicates that 'the small town rule' is a more powerful explanation than economic or local democracy perspectives (Johnsen \& Klausen, 2006).

More citizens are in favour of municipal amalgamation in 2015 than in early 2000, both in the principal and the contextual perspective (Lawrence Rose, Klausen, \& Winsvold, 2017). The tendency increases from 33\% (2003-2007) to almost $45 \%$ (2011) and up to 56\% (2015). Men are more positive than women, individuals aged more than 30 years are more in favour than younger individuals.. Additionally, individuals with high income, high education, and living in a municipality with over 5000 inhabitants are more in favour of mergers than citizens' who are more socioeconomic disadvantaged.However, the study from 2015 finds those socioeconomic variables decrease the impact on the contextual question. 
By and large, the citizens' views on the principle and the contextual perspectives are consistent. Party preferences have a significant impact on opinions of amalgamation, and this finding is similar to findings from previous years. Logically, the correlation between expecting positive results and being in favour of amalgamation is clear (Lawrence Rose et al., 2017).

Similar to the Australian study, a majority of the Norwegian respondents, however, believe that a municipal reform (amalgamation) will have no consequences for any of the topics in the questionnaire: consequences for local identity, the access to services (user-related), and the possibility of taking local political roles or performing citizenry (citizenship) (Lawrence Rose et al., 2017).

Our study may identify similar changes in citizens' attitudes in a region where no amalgamation reform has yet been implemented, such as in the national sample from 2015 (Lawrence Rose et al., 2017). Moreover, our study further explore the pattern that explains the attitudes and the possible changes. The model guides for the search of patterns of attitudes are created based on the independent variables: i) sociodemographic indicators, ii) political attitudes, iii) presumed consequences of amalgamation, and iv) their effect on the dependent variable, a pro- or antistand to reduce the number of municipalities.

\section{$3 \quad$ Research}

\section{Method}

The data used was from two surveys conducted in Inland Norway in 2013 and 2018. The 2013 survey had 532 respondents, out of the 2400 invited, and was technically conducted by Sentio (2014), a commercial survey company. The invitation was a proportional stratified random sample based on gender, region, and age group. A detailed representative analysis provided support to a weighting regime based on 140 strata. Two articles were published: one on municipal amalgamation (Higdem, Lesjø, Mønness, \& Høyer, 2016) and one on trust (Høyer \& Mønness, 2016). The 2018 survey had 1062 respondents; was technically collected by KantarTNS (2018), another commercial survey company; and based on their standing survey panel that had invited 2394 persons (the survey closed after a predefined number of respondents had replied). The panel was certified because of ISO-26362, and the analysis here was weighted because of standard procedure (KantarTNS, 2018).

Similar topics had equal questions in both surveys. Both surveys were skewed because higher education was overrepresented and the youngest age group was under-represented. This phenomenon has often been observed in this type of survey (personal communications; (Ipos-MMI, 2013; KantarTNS, 2018), see also Hellevik (2016)). Representation by region and gender were in good compliance in both samples. 
Because the 2013 sample was drawn from the general population, and the 2018 sample was drawn from a survey panel, a risk of noncomparability might be implied. However, the interest in politics was similar between the two samples (table 1). About 50\% in both samples are Reasonable interested in politics and 10$15 \%$ are very interested. Thus, the two samples were deemed comparable regarding political topics.

Table 1: Interest politics between the two polling groups, 2013 and 2018

\begin{tabular}{|l|c|c|}
\hline $\begin{array}{l}\text { How interested or uninterested are } \\
\text { you in politics in general? }\end{array}$ & Percent 2013 & Percent 2018 \\
\hline No interest whatsoever & $2 \%$ & $3 \%$ \\
\hline No special interest & $38 \%$ & $30 \%$ \\
\hline Reasonable interested & $50 \%$ & $53 \%$ \\
\hline Very interested & $10 \%$ & $14 \%$ \\
\hline $\mathrm{N}=$ & 530 & 1053 \\
\hline
\end{tabular}

\section{Data presentation and findings}

\section{Stance on amalgamation of own municipality.}

The main trend of our results is a profound change in citizens' attitudes on municipal amalgamation: from only $27 \%$ in favour in 2013 to nearly half the population (49\%) in favour in 2018 (table 2, grand mean). Over 5 years, a substantial number of opinions changed from scepticism to favouring municipal changes.

Table 2 shows the factors significant to citizens' stance on the amalgamation of their municipality, and the method used was ordinary least squares (OLS ) multiple regression analysis ${ }^{1}$. The factors were gender, centrality, level of education, degree of interest in politics, importance of geographical closeness to services, and partypolitical preferences. Centrality was defined as the citizens' residing in the municipalities of the central city-areas of the Inland and their surrounding municipalities: five city-regions encompassing 11 municipalities. ${ }^{2}$ The significant factors seem to be almost similar in the European context but do not necessarily demonstrate similar opinions (c.f.Calciolari et al., 2013), ).

A notable change was observed in the women's perspective. In 2013, women were less in favour of municipal amalgamation than men (27\% vs $41 \%)$, whereas in 
2018 , women's in-favour opinion increased to $43 \%$ in favour of amalgamationwhere the men's stance on this topic was stable (43\%).

Because citizens, in general, were being more positive regarding municipal amalgamation, the differences between citizens in the central and noncentral municipalities was reduced from 10\% in 2013 to $7 \%$ in 2018. The inhabitants of the city-regions were more sceptical of amalgamation than the noncentral inhabitants in 2013, despite the majority of citizens not being in favour. In 2018, $40 \%$ of the citizens of the central municipalities were in favour, compared to $47 \%$ in noncentral municipalities. The relationship between central citizens and noncentral citizens remained the same: More people were in favour of local amalgamation in noncentral areas compared with central city-areas.

Table 2: Percent of people in each group in favour of an amalgamation of own municipality, corrected for the other factors

\begin{tabular}{|c|c|c|c|c|}
\hline & & 2013 & 2018 & Difference \\
\hline Grand Mean & & $27 \%$ & $49 \%$ & $22 \%$ \\
\hline $\mathrm{N}=$ & & 473 & 926 & \\
\hline $\mathrm{N}=\mathrm{in}$ analysis below & & 453 & 895 & \\
\hline \multirow[t]{2}{*}{ Gender } & Female & $27 \%$ & $43 \%$ & $16 \%$ \\
\hline & Male & $41 \%$ & $43 \%$ & $2 \%$ \\
\hline \multirow[t]{2}{*}{ Municipal group } & $\begin{array}{l}\text { Noncentral, } 37 \\
\text { municipals }\end{array}$ & $39 \%$ & $47 \%$ & $7 \%$ \\
\hline & Central, 11 municipals & $29 \%$ & $40 \%$ & $11 \%$ \\
\hline \multirow{4}{*}{$\begin{array}{l}\text { How interested or } \\
\text { uninterested are you } \\
\text { of politics in general? }\end{array}$} & $\begin{array}{l}\text { No interest } \\
\text { whatsoever }\end{array}$ & $22 \%$ & $26 \%$ & $5 \%$ \\
\hline & No special interest & $25 \%$ & $41 \%$ & $17 \%$ \\
\hline & Reasonable interested & $40 \%$ & $50 \%$ & $10 \%$ \\
\hline & Very interested & $50 \%$ & $55 \%$ & $5 \%$ \\
\hline \multirow[t]{4}{*}{ Education } & $\begin{array}{l}\text { Primary/Secondary } \\
\text { School }\end{array}$ & $33 \%$ & $29 \%$ & $-4 \%$ \\
\hline & High School & $33 \%$ & $41 \%$ & $8 \%$ \\
\hline & University Bachelor & $26 \%$ & $48 \%$ & $22 \%$ \\
\hline & $\begin{array}{l}\text { University Master or } \\
\text { higher }\end{array}$ & $44 \%$ & $54 \%$ & $10 \%$ \\
\hline \multirow{2}{*}{$\begin{array}{l}\text { To what extent do } \\
\text { geographical } \\
\text { closeness influence }\end{array}$} & No or very small & $38 \%$ & $58 \%$ & $20 \%$ \\
\hline & Small & $47 \%$ & $53 \%$ & $6 \%$ \\
\hline
\end{tabular}




\begin{tabular}{|c|c|c|c|c|}
\hline \multirow[t]{3}{*}{$\begin{array}{l}\text { your trust to public } \\
\text { services? }\end{array}$} & $\begin{array}{l}\text { Neither small nor } \\
\text { large }\end{array}$ & $\begin{array}{c}\text { no } \\
\text { option }\end{array}$ & $44 \%$ & \\
\hline & Large & $32 \%$ & $39 \%$ & $7 \%$ \\
\hline & Very large & $20 \%$ & $22 \%$ & $2 \%$ \\
\hline \multirow[t]{10}{*}{ Political party } & $\begin{array}{l}\text { Labour Party, Social } \\
\text { democracy }\end{array}$ & $23 \%$ & $46 \%$ & $23 \%$ \\
\hline & $\begin{array}{l}\text { Progress Party, Right- } \\
\text { wing liberalism }\end{array}$ & $35 \%$ & $55 \%$ & $20 \%$ \\
\hline & $\begin{array}{l}\text { Conservative Party, } \\
\text { Liberal conservatism }\end{array}$ & $48 \%$ & $64 \%$ & $16 \%$ \\
\hline & $\begin{array}{l}\text { Christian Democratic } \\
\text { Party }\end{array}$ & $36 \%$ & $20 \%$ & $-16 \%$ \\
\hline & $\begin{array}{l}\text { Centre Party, } \\
\text { Agrarianism }\end{array}$ & $27 \%$ & $32 \%$ & $5 \%$ \\
\hline & $\begin{array}{l}\text { Socialist Left Party, } \\
\text { Democratic socialism }\end{array}$ & $21 \%$ & $30 \%$ & $9 \%$ \\
\hline & $\begin{array}{l}\text { Liberal Party, } \\
\text { Liberalism }\end{array}$ & $56 \%$ & $52 \%$ & $-4 \%$ \\
\hline & $\begin{array}{l}\text { Green Party, Green } \\
\text { politics }\end{array}$ & & $82 \%$ & \\
\hline & Red Party, Marxism & & $9 \%$ & \\
\hline & $\begin{array}{l}\text { Other party and/or no } \\
\text { revealed party } \\
\text { preference }\end{array}$ & $26 \%$ & $42 \%$ & $17 \%$ \\
\hline \multicolumn{5}{|c|}{$\begin{array}{l}\text { In } 2013 \text {, all factors have a } p<0.01 \text { except education, with } p=0.03 \text {. In } 2018 \text {, Gender is } \\
\text { not significant. Central municipals have } p=0.03 \text {, and the rest has } p<0.01 \text {. Green party } \\
\text { and Red party are very small parties. }\end{array}$} \\
\hline
\end{tabular}

In 2013, the higher a citizen's interest in politics, the more positive her or his attitude was towards amalgamating their municipality with neighbouring municipalities. However, as shown in table 2, in 2018, the correlation between interest in politics and positivism towards mergers are reduced. Individuals with no interest in politics whatsoever were stable, with approximately one quarter in favour. On the other side of the scale, individuals very interested in politics were stably in favour (50\%-55\%). Those citizens reporting no special interest in politics increased the most in percent of favour of amalgamation: from $25 \%$ to $41 \%$ in 5 years.

Education was also a factor that influences stance on municipal amalgamation. This phenomenon is especially notable for people with lower university degree, who beame significantly more positive towards amalgamation: from $26 \%$ in 2013 to $48 \%$ in 2018. Other education groups had a stable opinion, but the opinions of higher university-educated individuals were the most positive in 2013 (44\%) and even more positive (54\%) in 2018. Hence, the more education, the more positive 
the attitude towards amalgamation, and this pattern has been strengthened for the last 5 years.

How citizens assess the importance of geographical closeness regarding their trust in public services is critical for their stance on local municipal amalgamation. The more importance citizens attach to geographical closeness to services, the less positive they are regarding municipal amalgamation. This pattern was stable in the period. However, table 2 shows that the citizens attributing no significance to geographical closeness to their trust in public services altered considerably: from $38 \%$ (2013) to 58\% (2018) in favour of amalgamation.

As other studies have demonstrated (Calciolari, Cristofoli, and Macciò, 2013), the party preferences of citizens have been the most decisive factor related to being for or against municipal amalgamation. In 2013, discrepancies were observed between local party-supporters' attitudes to this question and the national parties' programmes. Only $23 \%$ of Labour Party voters were in favour of amagamation even thou the Party program was in favour. The Progress Party, part of the governmenet coallision having amalagamention as a very important reform, showed only $35 \%$ in favour of amalagamention. In 2018, supporters from almost all parties were increasingly in favour of amalgamation. Notably, the supporters of the parties in position (the Conservative Party and the Progress Party) moved from the majority not being in favour in 2013 to, respectively, 64\% and 55\% in favour. Additionally, the voters of the main opposition party, the Labour Party, increased their in-favour number from $23 \%$ to $46 \%$.

\section{Evaluation of amalgamation effects in general.}

The respondents provided their view on 14 topics about amalgamation effects in general. The scale was completely disagree, disagree, indifferent, agree, and totally agree. Table 3 shows what we call 'overweight': The given numbers are percent (totally agree plus agree) minus (disagree plus completely disagree). The evaluation of the 14 topics was somehow similar between years.

Table 3: Percent (totally agree plus agree) minus (disagree plus completely disagree) in 2013 and 2018. The numbers are called 'overweight'

\begin{tabular}{|l|c|c|}
\hline & 2013 & 2018 \\
\hline Enhance the (new) municipal's economic development & 35 & 25 \\
\hline Reduce the economic development in my current municipal & -3 & -13 \\
\hline Increase the competence in the municipal's administration & 46 & 41 \\
\hline Improve municipal services & 11 & 0 \\
\hline $\begin{array}{l}\text { Increase municipal position in the competition among } \\
\text { municipals }\end{array}$ & 34 & 27 \\
\hline
\end{tabular}


Attitudes Towards Territorial Municipal Reforms - The Case of Inland

Norway

\begin{tabular}{|l|c|c|}
\hline & 2013 & 2018 \\
\hline Parts of the new municipal will have a negative development & 10 & 17 \\
\hline Enhance local democracy & -13 & -37 \\
\hline Increase the distance between the public and the politicians & 36 & 44 \\
\hline Decrease local identity & 31 & 24 \\
\hline Build a new municipal identity & 28 & 8 \\
\hline Reduce the possibility for good services in remote areas & 35 & 23 \\
\hline Imply centralisation in the new municipal & 70 & 63 \\
\hline Personal services will improve & -12 & -16 \\
\hline $\begin{array}{l}\text { Citizen's ability to influence the development will be } \\
\text { reduced }\end{array}$ & 28 & 19 \\
\hline
\end{tabular}

We observed a decrease in citizens' assessing that an amalgamation would weaken the economic development of their current municipal unit. The overweight decreased from $-3 \%$ to $-13 \%$. However, the belief in an improved position among other municipals also decreased: from $34 \%$ to $27 \%$.

In 2013 , an $11 \%$ overweight believed an amalgamated municipality delivered better services, and in 2018, the citizens' opinion was divided into two equal parts (overweight $=0 \%$ ). In addition, there was almost a doubling of citizens' assessment of the likelihood of creating a negative development in parts of the new amalgamated municipality: from $10 \%$ to $17 \%$ overweight. The statement of weakening services in remote parts of the new municipals has gained less rating in 2018; however, an overweight by $23 \%$ (35\% in 2013) was observed. Fewer people now believe in improved public services for individuals: a decreases from minus $12 \%$ to minus $16 \%$. Most citizens' believed that amalgamation implied centralisation of public services: A belief that slightly decreased from minus $70 \%$ in 2013 to minus $63 \%$ overweight in 2018.

The overweight of citizens' who believed that amalgamation increases the distance between the public and the politicians increased from 36\% to $44 \%$. Few citizens' believed amalgamation would improve the local democracy in 2013 (overweight=-13), and even fewer in 2018 (-37\%). Additionally, fewer citizens' believed that amalgamation would weaken the ability to influence public development: from an overweight of minus $28 \%$ to minus $19 \%$.

Finally, a lesser part of the citizens' believed amalgamation would weaken the local identity (minus $31 \%$ to minus $24 \%$ ), and there was a strong decrease in believing in the possibility of creating a new identity of the new municipalities: only $8 \%$ overweight in the population. 
In summary, the opinion has become more positive towards municipal amalgamation during these 5 years. However, the citizens' views are increasingly polarised, and the belief in positive effects of amalgamation has been declining over the last 5 years. The data show that citizens' are less concerned about the economic effects and believe in increased competence of the municipal administration.

People agree on economic topics and disagree on democratic topics. In 2018, 'Enhance local democracy' and 'Build a new municipal identity' were highly rejected, and the respondents believed amalgamation implied centralisation. Thus, people do not consider amalgamation a democratic action.

\section{Structuring the amalgamation effects}

The 14 topics on amalgamation effects have an internal structure analysed by principal component analysis (PCA) and taking means (scores) guided by the PCA. The scale was coded completely disagree $=-2$ to totally agree $=+2$.

Table 4: Summary of PCA analysis

\begin{tabular}{|l|l|l|l|}
\hline \multicolumn{2}{|l|}{ PCA summary } & 2013 & 2018 \\
\hline $\begin{array}{l}\text { Kaiser-Meyer-Olkin Measure of Sampling } \\
\text { Adequacy }\end{array}$ & 0.926 & 0.959 \\
\hline Bartlett's Test of Sphericity & Approx. $\chi^{2}$ & 3152 & 7757 \\
\cline { 2 - 4 } & df. & 91 & 91 \\
\cline { 2 - 4 } & Significance. & 0.000 & 0.000 \\
\hline $\begin{array}{l}\text { Cumulative variance explained by 2 PCA } \\
\text { components out of 14, both with eigenvalues >1 }\end{array}$ & $73 \%$ & $70 \%$ \\
\hline
\end{tabular}

The summary of PCA analysis justified creating two components from the 14 topics. They captured in a satisfactory manner what we named AmalgamationPositive and AmalgamationNegative: They are negatively correlated (corr $=-0.639$ in 2013 and corr $=-0.757$ in 2018) (The question about the negative economic effect in my current municipal was grouped within the positive group but with opposite/negative sign). The raw means (not shown), of the two variable groups are close to the corrected overall means given i table 5. The Amalgamation Positive overall means are slightly above zero, the Amalgamation Negative overall means are about 0.5 (meaning agreement with negative arguments). The overall means are very stable from 2013 to 2018 . 
Figure 1: Distribution of AmalgamationPositive, both years

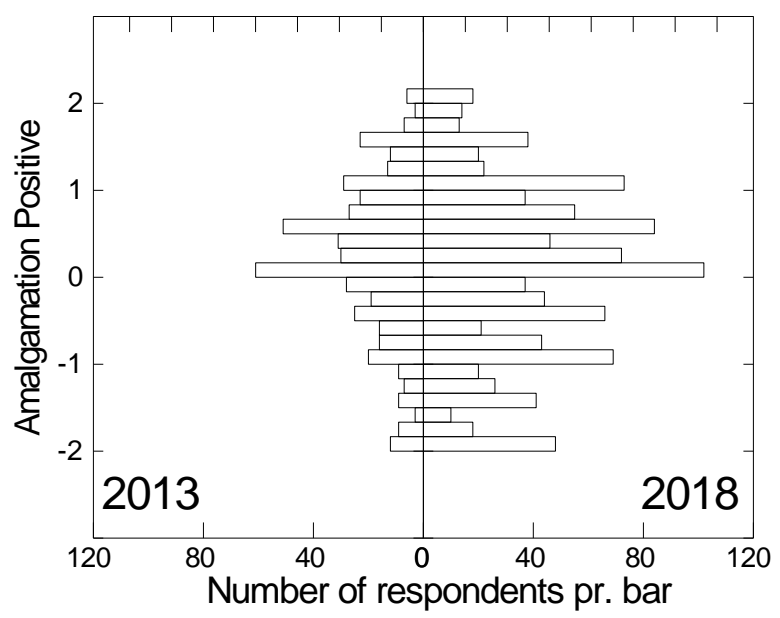

Figure 1 shows the distribution of AmalgamationPositive values. Even if there is the majority cluster around 'indifferent', many respondents agree or disagree completely on every topic.

Table 5: Estimated means of AmalgamationPositive and AmalgamationNegative, both years. The numbers are from a general linear model where values for every independent variable are corrected for the others. Only values where the variable had a significant $\mathrm{p}$ value are shown

\begin{tabular}{|c|c|c|c|c|c|}
\hline \multirow[t]{4}{*}{$\begin{array}{l}\text { completely } \\
\text { disagree }=-2\end{array}$} & totally agree $=2$ & \multicolumn{2}{|c|}{$\begin{array}{l}\text { Amalgamation } \\
\text { Positive }\end{array}$} & \multicolumn{2}{|c|}{$\begin{array}{l}\text { Amalgamation } \\
\text { Negative }\end{array}$} \\
\hline & Year $=$ & 2013 & 2018 & 2013 & 2018 \\
\hline & $\mathbf{N}=$ & 470 & 995 & 470 & 987 \\
\hline & R2 Adjusted= & 0.189 & 0.209 & 0.211 & 0.198 \\
\hline & & $\begin{array}{l}\text { Corre } \\
\text { value }\end{array}$ & $\begin{array}{l}\mathrm{d} \quad \text { Mean } \\
\text { group }\end{array}$ & $\begin{array}{l}\text { Corre } \\
\text { value }\end{array}$ & $\begin{array}{l}\text { Mean } \\
\text { roup }\end{array}$ \\
\hline Overall & & 0.169 & 0.044 & 0.499 & 0.420 \\
\hline Gender & $\mathrm{p}$ value & 0.133 & 0.519 & 0.816 & 0.533 \\
\hline
\end{tabular}


U. Higdem, H. C. Høyer, J. H. Lesjø \& E. N. Mønness: Changing Attitudes

Towards Territorial Municipal Reforms - The Case of Inland Norway

\begin{tabular}{|c|c|c|c|c|c|}
\hline \multirow[t]{2}{*}{$\begin{array}{l}\text { Municipal } \\
\text { group }\end{array}$} & $\mathrm{p}$ value & 0.807 & 0.895 & 0.025 & 0.957 \\
\hline & $\begin{array}{l}\text { Noncentral, } 37 \\
\text { municipals } \\
\text { Central, } 11 \text { municipals }\end{array}$ & & & $\begin{array}{l}0.553 \\
0.376\end{array}$ & \\
\hline \multirow{5}{*}{$\begin{array}{l}\text { How interested } \\
\text { or uninterested } \\
\text { are you of } \\
\text { politics in } \\
\text { general? }\end{array}$} & $\mathrm{p}$ value & 0.012 & 0.104 & 0.000 & 0.631 \\
\hline & No interest whatsoever & -0.047 & & 0.849 & \\
\hline & No special interest & 0.070 & & 0.592 & \\
\hline & Reasonable interested & 0.311 & & 0.404 & \\
\hline & Very interested & 0.440 & & 0.013 & \\
\hline \multirow[t]{4}{*}{ Education } & $\mathrm{P}$ value & 0.015 & 0.000 & 0.322 & 0.090 \\
\hline & $\begin{array}{l}\text { Primary/Secondary } \\
\text { School }\end{array}$ & 0.021 & -0.269 & & \\
\hline & High School & 0.085 & -0.051 & & \\
\hline & $\begin{array}{l}\text { University Bachelor } \\
\text { University Master or } \\
\text { higher }\end{array}$ & $\begin{array}{l}0.287 \\
0.381\end{array}$ & $\begin{array}{l}0.102 \\
0.309\end{array}$ & & \\
\hline \multirow{6}{*}{$\begin{array}{l}\text { To what extent } \\
\text { does } \\
\text { geographical } \\
\text { closeness } \\
\text { influence your } \\
\text { trust in public } \\
\text { services? }\end{array}$} & $\mathrm{p}$ value & 0.000 & 0.000 & 0.000 & 0.000 \\
\hline & No or very small & 0.297 & 0.235 & 0.190 & 0.054 \\
\hline & Small & 0.333 & 0.292 & 0.250 & 0.068 \\
\hline & Neither small or large & & 0.121 & & 0.190 \\
\hline & Large & 0.250 & -0.058 & 0.530 & 0.544 \\
\hline & Very large & -0.106 & -0.475 & 0.888 & 1.030 \\
\hline \multirow[t]{3}{*}{ Political party } & $\mathrm{p}$ value & 0.000 & 0.000 & 0.000 & 0.000 \\
\hline & $\begin{array}{l}\text { Labour Party, Social } \\
\text { democracy } \\
\text { Progress Party, } \\
\text { Conservative liberalism } \\
\text { Conservative Party, } \\
\text { Liberal conservatism }\end{array}$ & $\begin{array}{l}-0.010 \\
0.499 \\
0.638\end{array}$ & $\begin{array}{l}0.009 \\
0.153 \\
0.513\end{array}$ & $\begin{array}{l}0.513 \\
0.462 \\
-0.099\end{array}$ & $\begin{array}{l}0.481 \\
0.324 \\
-0.117\end{array}$ \\
\hline & $\begin{array}{l}\text { Christian Democratic } \\
\text { Party } \\
\text { Centre Party, } \\
\text { Agrarianism } \\
\text { Socialist Left Party, } \\
\text { Democratic socialism } \\
\text { Liberal Party, Liberalism }\end{array}$ & $\begin{array}{l}0.184 \\
-0.064 \\
-0.127 \\
0.306\end{array}$ & $\begin{array}{l}-0.015 \\
-0.282 \\
-0.062 \\
0.576\end{array}$ & $\begin{array}{l}0.509 \\
0.503 \\
0.830 \\
0.394\end{array}$ & $\begin{array}{l}0.373 \\
0.751 \\
0.596 \\
-0.072\end{array}$ \\
\hline
\end{tabular}




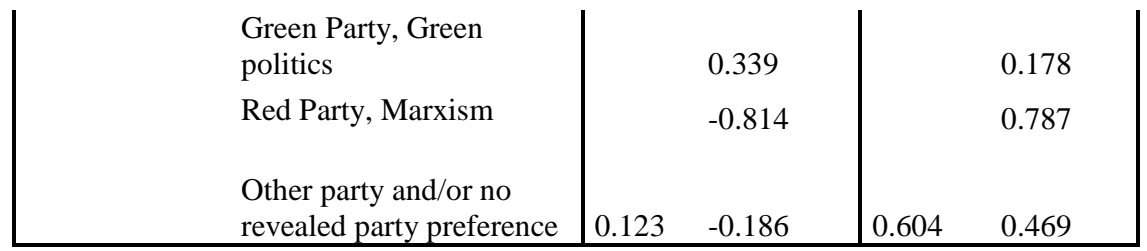

Table 5 shows estimated group means of AmalgamationPositive and AmalgamationNegative for both years. The means are results from an OLS multiple regression, and the independent variables are the same as in table 2. Only values of significant factors are shown. Increasing interest in politics implies higher agreement in positive arguments and lesser agreement with negative arguments, at least so in 2013. The differences in 2018 are not significant. Increasing education implies more agreement with positive arguments both in 2013 and 2018. Geographical closeness shows an expected pattern for both years and positive and negative arguments: less agreement on positive topics and more agreement with negative topics. Notably, the Progress Party has decreased its agreement with a positive argument (from 0.499 to 0.153 ) but increased its stand on actual amalgamation from $35 \%$ to $55 \%$ (table 2). The supporters of the Conservative Party shows a stable opinion on the arguments (table 5) but an increased stand on actual amalgamation from $48 \%$ to $64 \%$ (table 2). Also the respondents identifying with the Labour Party shows this pattern, stable on argumments, increased stand on actual amalgamation from 23\% to $46 \%$ (table 2). The respondents favoring the Centre Party shows increased agreement with negative arguments but shows a slightly increased stand for actual amalgamation. The Socialist Left Party's supporters also agree with negative arguments but have an increased stand on actual amalgamation from $21 \%$ to $30 \%$. Respondents faovring the Liberal Party shows an increased agreement with positive arguments but strangely a small decreased stand on actual amalgamation. 
Figure 2: Estimated probability of voting for amalgamation of own municipal, given the level of seeing positive effects of municipal amalgamation in general, 2013 and 2018

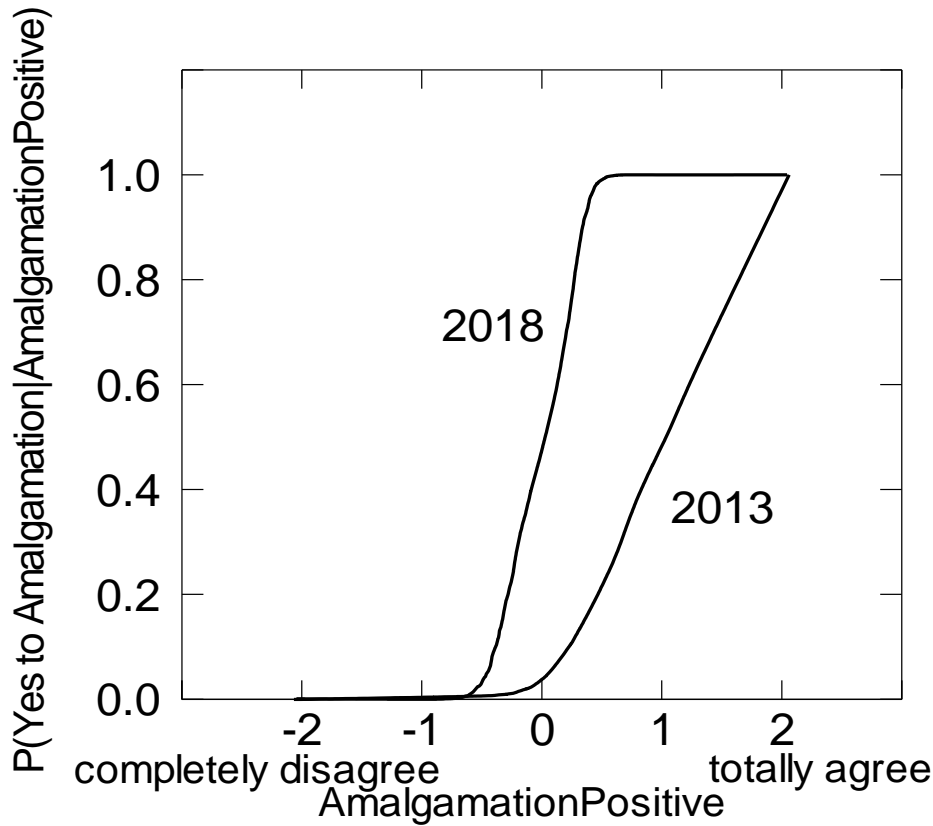

Relation between the perspective of amalgamation effects in general and stance on amalgamation of own municipality.

Figure 2 depicts the nonparametric (LOWESS regression) estimated probability of voting for amalgamation of own municipality given the level of the agreement of positive effects of municipal amalgamation in general in 2013 and 2018. In 2013, an arbitrary sceptical person would surely have voted against amalgamation. Only if nearly in total agreement with positive amalgamation arguments would an individual have a high probability to vote in favour of amalgamation. The weak slope of the 2013 curve depicts this. By contrast, the 2018 slope is very steep around AmalgamationPositive $=0$. The switch from voting No to Yes is nearly immediate at this point. The compliance between seeing positive effects of amalgamation and taking a stance for amalgamation of an individual's own municipality has increased substantially from 2013 to 2018. 


\section{Discussion}

The national reform initiated from the Conservative-Progress government in 2013/14 led to 47 amalgamations involving 120 municipalities. These mergers were almost countrywide, with the stronghold of the country south of Oslo, the capital, and with municipalities in Vestfold county leading the change. The Inland region was the only region with no mergers ${ }^{3}$, except for the capital of Oslo; Oslo holds the status both a municipality and a county.

The county governors were allocated the special task of promoting the reform process in their regions of responsibility, and the governors of Oppland and Hedmark recognised the necessity of future reforms in larger municipal entities. These two governors used different strategies as municipal advisers: Oppland was very active in arguing for reforms and modernisation that implied amalgamation, and Hedmark showed a more laid-back attitude. The results were, however, similar in both counties: no amalgamation.

This scepticism towards reform among local politicians corresponds to a deep attitude embedded in the regions' public opinion, which probably reflects the regions' history as a class-based periphery in the inner part of the country. The Labour Party and the traditional agrarian party (Centre Party) have dominated local politics with a longstanding scepticism towards elites in urban centres. In other peripheral areas, in the west and in the north of the country, reforms were achieved, although only one amalgamation was observed in the northernmost county of Finnmark.

Although the attitudes towards reform seem to have gradually changed, this might reflect the difficulties outside of the mainstream changes in the future national landscape of local governments. The national initiated reform will continue in one form or another (KMD 2019). The two counties of Hedmark and Oppland will be merged into an Inland county starting in 2020. This decision was imposed on the region against the majority of the regionally elected politician's preferences, which may have contributed to the shift in opinion on municipal amalgamation. The administration responsible for the national government will maintain the pressure for amalgamation reform; hence, more Inland-citizens' are likely to give in to such continuous pressure.

Substantial concerns remain regarding the future of local government affairs in the region. Demographic data indicates a population decline in most of the municipalities, contrary to the increasing population in the nation at large. This regional decline simultaneity implies an ageing population in rural areas, forcing local politicians in many municipalities to reallocate resources away from schools and education to focus on health and welfare services. Although amalgamation is 
no quick fix for municipalities with a small population scattered in larger territories, the 'realities' of modernisation and the national pressure for reform slowly crowds in.

\section{Other research results - comparisons}

Our analysis validates an overall trend in public opinion similar to another analysis based on national samples. The attitude of the public is less negative towards municipal amalgamation than in earlier years. This finding applies to Inland Norway as well, despite the topic remaining contested, and is on the national agenda. The majority in the national sample from 2015 (Lawrence Rose et al., 2017) was still not in favour of reform, such as in this study. However, the trend is clear; the central government gained more acceptance for their amalgamation policy compared with some decades ago.

Other patterns of similarity among the research findings are notable. First, the strong correlation between stands regarding the reform and political party sympathies. Respondents from the Centre Party and the left parties (Socialist Left and the Red party) are clearly against reforms. Respondents identifying with the Conservative Party and Progress Party are in favour because these parties hold the power in the current government, and lead the amalgamation-reform. One exception in the data is the sympathisers of the Christian Democratic Party, who were less in favour of reform in 2018 than in 2013, and this finding contradicts the findings in the national sample. The largest change in the other direction is the Progress Party sympathisers: a 20 percentage-point increase in the positive direction. We also observed a move in majority from against to pro-reform.

The findings regarding the sociodemographic variables seem to be robust. The level of education is critical in explaining the respondents stand; respondents with a university degree are positive, and citizens with only primary school are negative. The same situation applies to the variable 'interest in politics', where people with 'no interest in politics what so ever' have attitudes significantly more negative to reform than the other respondents. Together, a pattern emerges indicating that people most remote from the political system are the most sceptical of national 'elites" plans for municipal reforms. The pattern seems to be robust, a finding also found in the international literature.

Regarding the influence of gender, the 2018 data deviate from earlier studies reported in international studies and in other Norwegian stydues. Although most studies have indicated that women are more critical of merging municipalities into larger units, this was not the case in the present 2018 survey: No differences in attitude between men and women were found. Whether this finding reflects a substantial shift from women's more conservative stand, it is too early to say, but this aspect would obviously be of interest for further research. 
The data shows that respondents in noncentral areas are more in favour of amalgamation than respondents in the central parts of the Inland regions, even if the differences decreased since the 2013 survey. This finding seems odd and contradicts some international patterns shown in the literature. Nevertheless, the reasons may be found in the 'small town rule', that is, people living in small locales nearby a larger town are the most strongly against amalgamation with the largest unit. Therefore, in these regions, the centre-periphery relations are at work.

\section{Expectations}

Now, we return to the discussion of the two main possible empirical expectations, the rational or the socially embedded, which we initially introduced. We aimed for the two models to help explain the apparent inconsistency in the findings, where the degree of critical arguments and consent to possible negative effects has increased substantially, concurrent with a shift from citizens being overall negative towards amalgamation to almost $50 \%$ being in favour of mergers. Consequently, the first rational assumption of a clear and unambiguous connection between the citizens' estimations of negative consequences of amalgamation and their standpoint to amalgamation of the own municipality is not the case. However, respondents who in 2018 were aware of the many positive results are in favour of their municipality merging with the neighbouring municipalities and are, therefore, meeting the rational expectation; this was not the case in 2013.

The third expected topic emphasises that citizens are rational utilising single individuals and assumes that citizens' views on municipal mergers are influenced by the characteristics of the citizens, that is, the interests citizens' associate with or are loyal to. Our analysis, show that the citizens' position on municipal mergers is influenced by their political party affiliation, education, and professional background. That education and profession influence citizens' stand for municipal mergers is in accordance with the third rational perspective, that is, the individual attitudes to reform reflect the stand of the preferred political party. This finding is also in accordance with the third social-embedded theory perspective, that is, citizens' evaluations are in general influenced by their belonging to and identification with political values parties, groups, and so forth, and what citizens consider an appropriate stand in their community of residence.

However, the findings show that citizens' are less concerned about the economic effects and beliefs in increased competence of the municipal administration and more sceptical regarding if amalgamation would improve the provision of services, local democracy, and a new common municipal identity. Therefore, the findings may also suggest that citizens' value enhances the municipal economy, and a strengthened local competence as a form of efficiency is valued over local democracy and identity. Such interpretations of the findings may be in line with a rational framework. 
The findings correspond to the first social-embedded expectation stating there is no necessary connection between the citizens' assumptions of costs and benefits from a municipal merger and their own stand on the topic. Such an explanation indicates a decline in opposition to municipal mergers in the actual period. The reasoning that emanates from the emphasis of the citizens as community-seeking individuals is that citizens over time will turn to the idea and accept the municipal merger. Notably, such a change in attitude does not imply that citizens accept, or eventually realise, that the merger will have more positive effects than they did earlier. By contrast, citizens are increasingly noticing negative effects of a merger while simultaneously accepting and saying yes to mergers. The third socialembedded expectation, however, assumes that the citizens' assessments are influenced by the connection they have to their municipality and other characteristics that can be assumed to affect what they perceive as an appropriate standpoint on municipal merging, given their fundamental values and identity.

A social-embedded explanation of the data suggests citizens' resignation or compliance regarding the rather massive and ongoing national pressure on municipality mergers, rather than a real change in their views on amalgamations.

\section{5}

\section{Conclusions}

This paper reports on citizens' attitudes to territorial reforms encouraging municipal amalgamation. Guiding the study was two main questions; first, did opinions change during the period of reform, and second, how did this change eventually take shape. We use data from Inland Norway, where no mergers had occurred, contrary to the situation elsewhere in Norway. We had reason to believe this region would be the latest region to accept this type of reform because of its socioeconomic and political context. Thus, this case is critical if changes are identified in this region, and a more general change of opinion on this topic may occur nationally.

Our study shows a considerable change in attitude towards the reform during the 5-year period of 2013 to 2018 to a more positive one, from $27 \%$ to $49 \%$. However, a majority was not in favour. Changes seem to not be a result of new and more positive judgements of the reforms' results and outcome. By contrast, the majority has been more critical of anticipated consequences of the amalgamation reform into larger municipalities.

What we observe are, therefore, not so much attitude changes corresponding with the rational model that anticipates that the stand to the reform should be a reflection of what they think the reform would be leading to. The findings corresponds overall more to fit with the social-embedded perspective lined up in the introduction. The changes towards more positive attitude to amalgamation occurs without the respondents necessarily being more optimistic concerning 
expectations that better services had to follow. This could be seen as a type of 'resignation' towards a reform pressure from the national government and general changes in peoples' environment. Notably, more citizen assess a positive municipal economic development, and more local competence is a favourable effect of mergers, and both support this claim. The reform is likely to catch up with its local units anyway, and citizens' attitudes are adapting to what their expectations are of what will occur in the upcoming years. In addition, individuals who anticipated positive effects are now definitely more in favour of amalgamation of their municipality.

This, of course, may be providing the government and the reform supporters a window of opportunity for new decisions in the years ahead. The legitimacy of the process will be challenged, but what type of decision rules are established probably has large consequences for the results. If the local governments pass local referendums on the topic, a polarised situation will again occur, and implementing the reform on a large scale would be difficult. If local politicians, as the national government prefers, limit citizens' participation in the topic to having a say in local meetings and being respondents in representative surveys, the outcome will certainly be different and more positive for the reforms' success.

\section{Notes:}

${ }^{1}$ A logistic regression solution for the 2013 data does not exist due to a quasi-complete separation in the model. With the 2018 data, both regression methods give nearly identical percentage values and significance levels. OLS gives unbiased estimates independent of the sampling distribution of the residuals.

2 The Hamar-region (Hamar, Stange, Ringsaker and Stange municipalities), the Lillehammer-region (Lillehammer and Øyer municipalities), the Gjøvik-region (Gjøvik, Østre Toten and Vestre Toten municipalities, and finally Elverum and Kongsvinger.

${ }^{3}$ No municipality in Aust(=East)-Agder was merged, but several in Vest(=West)-Agder. Aust- and Vest-Agder will be one county starting in 2020.

\section{References:}

Calciolari, S., Cristofoli, D. \& Macciò, L. (2013) Explaining the reactions of Swiss municipalities to the 'Amalgamation wave', Public Management Review, 15(4), pp. 563-583.

Christensen, T., Lægreid, P. \& Røvik, K. A. (2015) Organisasjonsteori for offentlig sektor (Oslo: Universitetsforlaget).

Ebinger, F., Kuhlmann, S. \& Bogumil, J. (2019) Territorial reforms in Europe: effects on administrative performance and democratic participation, Local Government Studies, 45(1), pp. 1-23, https://doi.org/10.1080/03003930.2018.1530660.

Grenwood, R., Oliviver, C., Sahlin, K. \& Suddaby, R. (2008) The SAGE Handbook of Organizational Institutionalism (London: Sage). 
Hall, P. A. \& Taylor, R. C. R. (1996) Political Science and the Three New Institutionalisms, Political Stuidies, 44(5), pp. 936-957.

Hardin R. (2002) Trust and Trustworthiness (New York: Russel Sage Foundation).

Hellevik, O. (2016) Extreme nonresponse and response bias, Quality \& Quantity, 50(5), pp. 1969-1991, https://doi.org/10.1007/s11135-015-0246-5.

Higdem, U., Lesjø, J. H., Mønness, E. \& Høyer, H. C. (2016) Større kommuner og fylker? Reflektert syn blant innbyggerne, og konklusjonen er nei, Fagbladet Samfunn og Økonomi, 1, pp. 9-28.

Høyer, H. C. \& Mønness, E. N. (2016) Trust in public institutions - spillover and bandwidth, Journal of Trust Research, 6(2), pp. 151-166, https://doi.org/10.1080/21515581.2016.1156546.

Ipos-MMI (2013) Norsk Monitor - En sosiokulturell studie, available at: http://ipsosmmi.no/Norsk-Monitor (October 12, 2019).

Jacobsen, D. I. (2004) Holdninger til endring i kommunestruktur: En nyansering av Rose og Pettersen, Norsk Statsvitenskapelig Tidsskrift, 20, pp. 414-420.

Johnsen, Å. \& Klausen, J. E. (2006) Kommunesammenslåingers politiske økonomi. En analyse av velgeratferd i rådgivende folkeavstemninger, Norsk Statsvitenskapelig Tidsskrift, 22, pp. 22-45.

KantarTNS (2018) Norsk gallup, available at: https://kantar.no/ (October 12, 2019).

Kushner, J. \& Siegel, D. (2003) Effect of Municipal Amalgamations in Ontario on Political Representation and Accessibility, Canadian Journal of Political Science / Revue canadienne de science politique, 36(5), pp. 1035-1051.

March, J. G.ž, \& Olsen, J. P. (1995) Democratic Governance (New York: The Free Press).

Poel, D. H. (2000) Amalgamation Perspectives: Citizen Responses to Municipal Consolidation, Canadian Journal of Regional Science, 23(1), pp. 31-48.

Rokkan, S. (1987) Stat, nasjon, klasse (5 ed.) (Oslo: Universitetsforlaget).

Rose, L., Klausen, J. E. \& Winsvold, M. (2017) Holdninger til kommunereform: Hva er utslagsgivende?, In: S. Jo \& D. A. Christensen (eds) Lokalvalget 2015 - et valg $i$ kommunereformens tegn? (Oslo: Abstract forlag AS), pp. 267 - 300.

Rose, L. \& Pettersen, P. A. (2003). Holdninger til endringer i kommunestruktur: To preferanser, to rasjonaliteter?, Norsk Statsvitenskapelig Tidsskrift, 19, pp. 240-275.

Rose, L. \& Pettersen, P. A. (2005) Endringer i kommunestrukturen. Hva skiller motstanderne fra de velvillige?, In: Saglie, J. \& Bjørklund, T. (eds) Lokalvalg og lokalt folkestyre (Oslo: Gyldendal Akadmisk), pp. 288-318.

Ryan, R., Hastings, C., Grant, B., Lawrie, A., Ní Shé, É. \& Wortley, L. (2016) The Australian Experience of Municipal Amalgamation: Asking the Citizenry and Exploring the Implications, Australian Journal of Public Administration, 75(3), pp. 373-390, https://doi.org/10.1111/1467-8500.12182.

Sentio (2014) Sentio Research, available at: http://www.sentio.no/ (October 12, 2019).

Swianiewicz, P. (2018) If territorial fragmentation is a problem, is amalgamation a solution? - Ten years later, Local Government Studies, 44(1), pp. 1-10, https://doi.org/10.1080/03003930.2017.1403903.

Verhoeven, I. \& Duyvendak, J. W. (2016) Enter emotions. Appealing to anxiety and anger in a process of municipal amalgamation, Critical Policy Studies, 10(4), pp. 468-485, https://doi.org/10.1080/19460171.2015.1032990. 